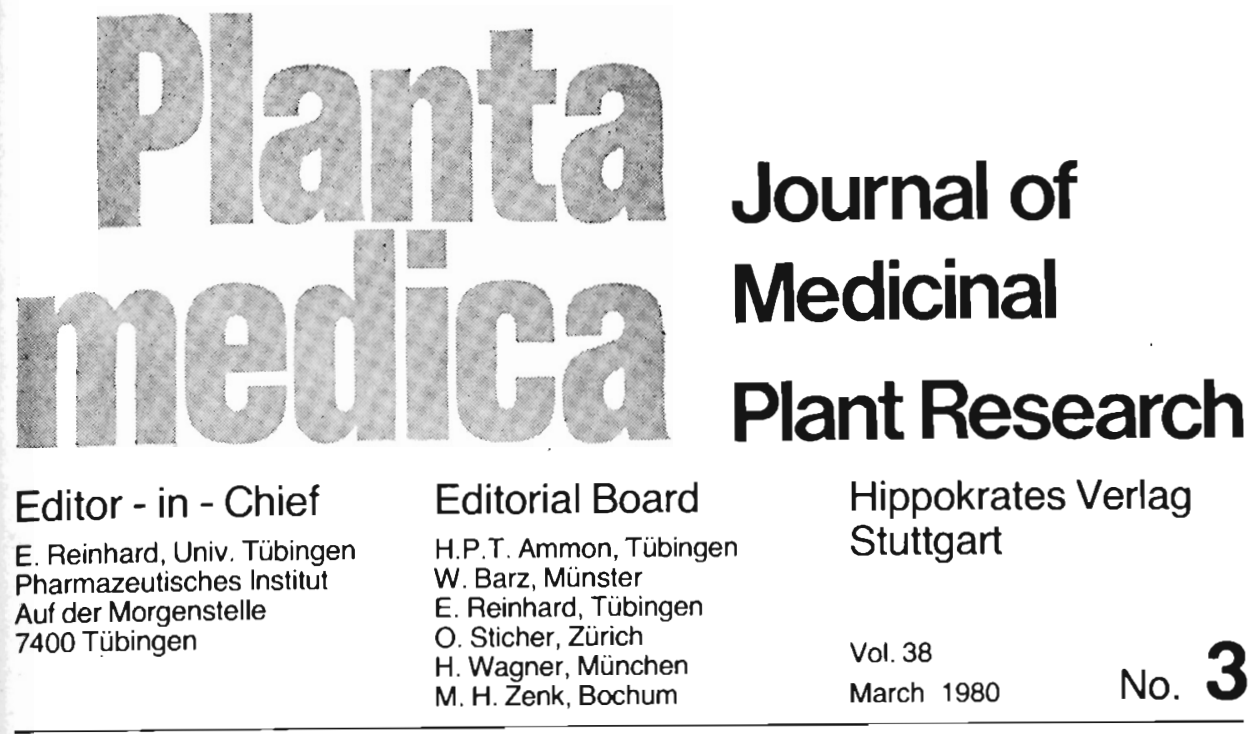

\title{
Naturally Occurring Isohexenylnaphthazarin Pigments: A New Class of Drugs
}

V. P. Papageorgiou

Laboratory of Organic Chemistry College of Engineering Aristotle University of Thessaloniki, Greece.

Key Word Intex: Boraginaceae; Alkannin; Shikonin; Naphthazarin; Biosynthesis; Antibacterial Activity; Antitumor Activity; Cytotoxiçity; Wound Healing.

\section{Abstract}

The chemistry, biosynthesis, biological properties and the wound healing activity of isohexenylnaphthazarin pigments are being reviewed. Dermatological studies indicate that these long known plant products may be regarded as a new class of drugs.

\section{Introduction}

The isohexenylnaphthazarins, commonly known às alkannins, are lipophilic red pigments $[1,2,3]$. They were found in the outer surface of the roots of at least a hundred and fifty species that belong to the genus Lithospermum, Echium, Onosma, Anchusa and Cynoglossum of 
the family Boraginaceae [1]. Their occurrence in Jatropha glandulifera, a member of the Euphorbiaceae, should be considered as an exception $[4,5]$.

The use of alkannins as dyes was known to ancient Greeks and Romans who employed the roots of Anchusa tinctoria or Alkanna tinctoria for this purpose. The wound healing properties of these roots were discribed by Dioscorides.

The healing properties of the extracts of Lithospermi radix (Shikon) attracted the attention of the Chinese who used them as folk remedies, even though the coloring properties were known to them and to other nations in the Far East. Even today the inhabitants of India and Pakistan employ these dyes [6,7]. Among the plants used for this purpose is Arnebia nobilis. A detailed study on the pigments in this plant has shown that these are mixtures of alkannin and its esters $[8,9]$.

Although the wound healing activity of alkannin was known all over the world, such use has faded away with time. Ironically the use as a food colorant $[10,11]$ survived and is still used as such in our days. At least twelve European countries allow its use as colorant in food and wine.

Alkannin attracted the attention of chemists in the forties when it was used for a short period as an analytical reagent with limited success $[12,13]$.

\section{Chemistry}

All presently known naturally occurring isohexenylnaphthazarins are listed in Table I. The structural features common to all these pigments are the naphthazarin moiety and the isohexenyl side chain. Whereas they differ in the follow- ing respects: (1) their manner of rotating polarised light (chirality), (2) the position of the alcoholic group in the side chain, and (3) the acid moiety which esterifies the alcoholic group.

Alkannin, the first identified member $\bar{\theta}$ of the naphthazarins, was isolated from two European varieties, Alkanna tinctoria $[14,28,29]$ and Onosma echioides [30, 31]. Its structure was elucidated by BrockMANN [14] and found to be the laevo-. rotatory 5,8-dihydroxy-2-(1'-hydroxy-4'methylpent-3'-enyl)-1,4-naphthaquinone (Table I, Nr. IV). The antipode of alkannin, shikonin, was isolated by Majma and Kuroda [32] from the roots of Lithospermum erythrorbizon (Shikon in Japanese) but was correctly identified only by Brockmann [14] who established its close identity with alkannin. The Japanese pigment was not only dextrorotatory but its specific rotation was less than that of the laevorotatory alkannin; hence it was considered to be a mixture of $( \pm)$ alkannin (named shikalkin) and $(+)$ alkannin (called shikonin) in the ratio $1: 4$.

The absolute configuration of shikonin has been studied by Arakawa and NaKaZAKI [33]. Shikonin (XVII) was subjected to ozonolysis in acetic acid solution and subsequently treated with hydrogen peroxide. The resulting dimethyl malic acid ester (XVIII) was converted into the amide and found to be identical with $\mathrm{D}(+)$ malamide (XIX). Hence shikonin was found to have (R) - and alkannin the $(S)$ - configuration (Fig. 1).

During the isolation from the plant material some of the pigments shown in Table I formed artifact naphthaquinones. Thus, the cyclic ether XX was formed [9] during the alkaline hydrolysis of arnebin-2 (Table I, Nr. XIV). 


\section{Table I}

The up-today reported naturally occurring isohexenylnaphthazarin pigments<smiles>[R]C1=CC(=O)c2c(O)ccc(O)c2C1=O</smiles>

\begin{tabular}{|c|c|c|}
\hline Nr. & $\mathrm{R}$ & Name [Reference] \\
\hline I & $-\mathrm{CH}_{2} \mathrm{CH}_{2} \mathrm{CH}_{2} \mathrm{CHMe}_{2}$ & Alkannan [14] \\
\hline II & $-\mathrm{CH}_{2} \mathrm{CH}_{2} \mathrm{CH}=\mathrm{CMc}_{2}$ & $\begin{array}{l}\text { Deoxyalkannin }[15,16] \text { or Deoxyshikonin }[17] \text { or } \\
\text { Arnebin-7 }[18]\end{array}$ \\
\hline III & $-\mathrm{CH}=\mathrm{CHCH}=\mathrm{CMe}_{2}$ & Anhydroalkannin [17] \\
\hline IV & $-\mathrm{CH}(\mathrm{OH}) \mathrm{CH}_{2} \mathrm{CH}=\mathrm{CMe}_{2}$ & Alkannin $[7,8,14,19,20,25]$ or Shikonin $[21,22]$ \\
\hline V & $\begin{array}{l}-\mathrm{CHCH}_{2} \mathrm{CH}=\mathrm{CMe}_{2} \\
\mathrm{OCOCH}_{3}\end{array}$ & Acetylalkannin $[16]$ or Acetylshikonin $[4,23]$ \\
\hline VI & $\begin{array}{l}-\mathrm{CHCH}_{2} \mathrm{CH}=\mathrm{CMe}_{2} \\
\mathrm{OCOCHMe}_{2}\end{array}$ & Isobutylshikonin [23] \\
\hline VII & $\begin{array}{l}-\mathrm{CHCH}_{2} \mathrm{CH}=\mathrm{CMe}_{2} \\
\mathrm{OCOCH}_{2} \mathrm{CHMe}_{2}\end{array}$ & Isovalerylalkannin $[16,24]$ or Isovalerylshikonin [17] \\
\hline VIII & $\begin{array}{l}-\mathrm{CHCH}_{2} \mathrm{CH}=\mathrm{CMe}_{2} \\
\mathrm{OCOCHMeCH} \\
\mathrm{OCHe}_{2} \mathrm{Me}\end{array}$ & $\begin{array}{l}\alpha \text {-Methyl-n-butyl-alkannin [16] or } \\
\alpha \text {-Methyl-n-butyl-shikonin [17] }\end{array}$ \\
\hline IX & $\begin{array}{l}-\mathrm{CHCH}_{2} \mathrm{CH}=\mathrm{CMe}_{2} \\
\mathrm{OCOCH}=\mathrm{CMe}_{2}\end{array}$ & $\begin{array}{l}\beta, \beta \text {-Dimethylacryl-alkannin }[8,16,25] \text { or } \\
\beta, \beta \text {-Dimethylacryl-shikonin }[4,23]\end{array}$ \\
\hline$X$ & $\begin{array}{l}-\mathrm{CHCH}_{2} \mathrm{CH}=\mathrm{CMe}_{2} \\
\mathrm{OCOC}(\mathrm{Me})=\mathrm{CMe}_{2}\end{array}$ & Teracrylshikonin [26] \\
\hline $\mathrm{XI}$ & $\begin{array}{l}-\mathrm{CHCH}_{2} \mathrm{CH}=\mathrm{CMe}_{2} \\
\mathrm{OCOC}(\mathrm{Me})=\mathrm{CHMe}\end{array}$ & Angelicalkannin [24] or Angelicshikonin [15] \\
\hline XII & $\begin{array}{l}-\mathrm{CHCH}_{2} \mathrm{CH}=\mathrm{CMe}_{2} \\
\mathrm{OCOCH}_{2} \mathrm{C}(\mathrm{OH}) \mathrm{Me}_{2}\end{array}$ & $\beta$-Hydroxy-isovaleryl-shikonin [26] \\
\hline XIII & $\left.\right|_{\mathrm{OCOCH}_{2} \mathrm{C}\left(\mathrm{OCOCH}_{3}\right) \mathrm{Me}_{2}} ^{-\mathrm{CHCH}_{2} \mathrm{CH}=\mathrm{CMe}_{2}}$ & $\beta$-Acetoxy-isovaleryl-alkannin [27] \\
\hline XIV & $\begin{array}{l}-\mathrm{CHCH}_{2} \mathrm{CH}_{2} \mathrm{C}(\mathrm{OH}) \mathrm{Me}_{2} \\
\mathrm{OCOCH}=\mathrm{CMe}_{2}\end{array}$ & $\beta, \beta$-Dimethylacryl-hydroxy-alkannin or Arnebin-2 [9] \\
\hline $\mathrm{XV}$ & $\left.\right|_{\mathrm{OCOCH}_{3}} ^{-\mathrm{CHCH}_{2} \mathrm{CH}_{2} \mathrm{C}(\mathrm{OH}) \mathrm{Me}_{2}}$ & Acetyl-hydroxy-alkannin or Arnebin-6 [9] \\
\hline XVI & $-\mathrm{CH}_{2} \mathrm{CH}_{2} \mathrm{CH}_{2} \mathrm{C}(\mathrm{OH}) \mathrm{Me}_{2}$ & Hydroxy-alkannan or Arnebin-5 [9] \\
\hline
\end{tabular}


<smiles>CC1=CC[C@](C)(O)C2=C1C(=O)c1c(O)ccc(O)c1C2=O</smiles>

XVII<smiles>CCCCC(=O)OC</smiles>

XVIII<smiles>NC(=O)CC(O)C(N)=O</smiles>

$x i x$

Fig. 1: Determination of absolute configuration of shikonin [33].<smiles></smiles>

$x x$<smiles>CC=CC(C)=O</smiles>

$x \times 1$<smiles>CC1CCC(O)C2=C1C(=O)c1c(O)ccc(O)c1C2=O</smiles>

XXII<smiles>CC1CCCC2C(=O)c3c(O)ccc(O)c3C(=O)C12</smiles>

$x \times$ III
It has also been reported [34] that during isolation of shikonin angelate (Table I, Nr. XI), the side chain cyclised to give the unusual four-membered ring system XXI.

Some shikonin derivatives, such as dihy- droshikonin (XXII) and 8-hydroxy-2isohexyl-4-oxo-tetralone (XXIII), which had not been reported previously, were prepared by catalytic reduction of shiko$\operatorname{nin}$ [35].

A study on 'H-NMR spectra of some of the discussed naphthaquinones has also been reported [36]. In case of alkannin an alternative structure was thus postulated. Because of the disturbance of the - ronic equilibrium of the quinonoid

\section{Biosynthesis}

ring the formation of the tautomer structure $\mathrm{XXIV}_{\mathrm{b}}$ is favoured

${ }^{13} \mathrm{C}-\mathrm{NMR}$ data for naphthazarin and their methyl ethers and acetates have also been published [37].

Alkannin is considered as the representative naphthazarin pigment for a stu$\mathrm{dy}$ of the biosynthesis of these pigments. At first Neelakantan and Seshadri suggested that the probable biosynthetic sequence involved lengthening of the side chain of 2-methyl-naphthazarin (XXVI) by a $\mathrm{C}_{5}$-isoprene unit [38]. The formation of 2-methyl-naphthazarin itself was postulated to arise from 3,5-dihydroxyphthalic acid (XXV) or phthalaldeyde involving stages of nuclear dehydroxylation and nuclear hydroxylation as shown in Figure 2.

Shukla et al. [9], although tracer studies were not carried out, suggested that the alkannin molecule might be derived 


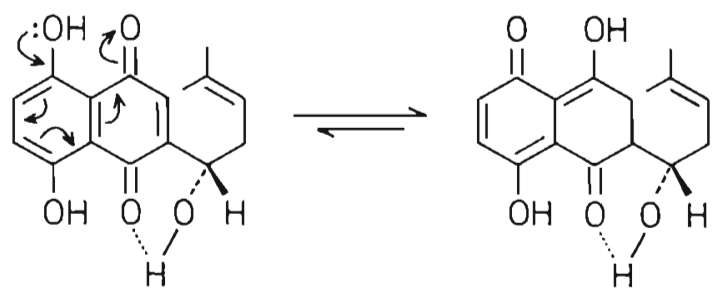

XXIVa

XXIVD

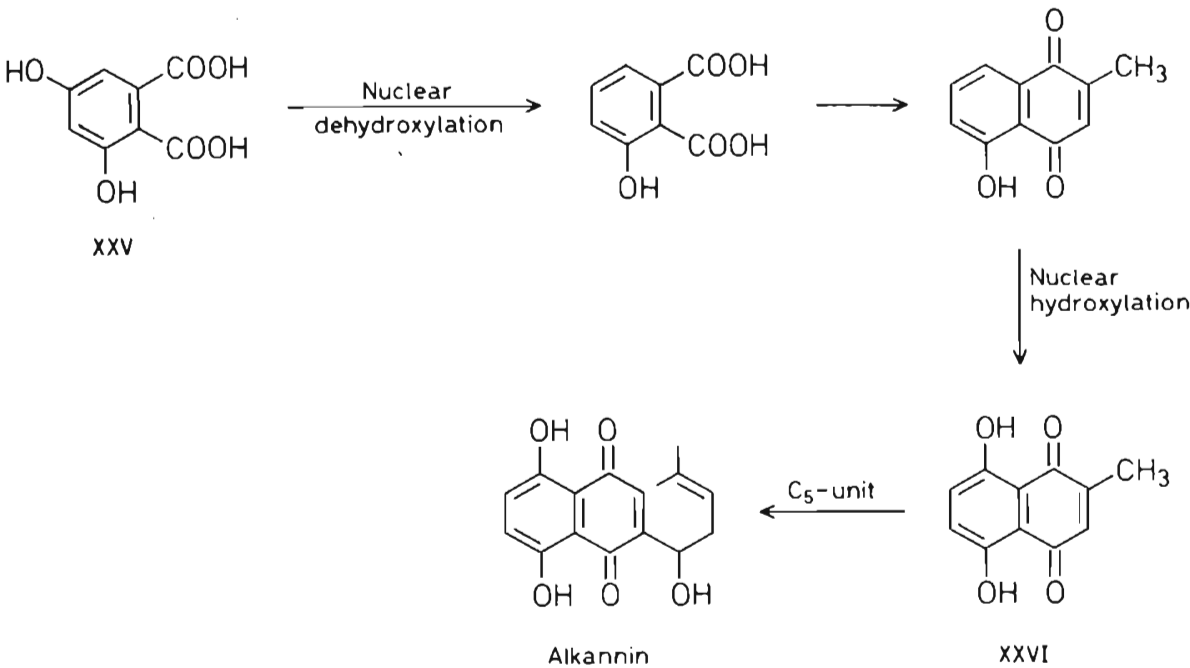

Fig. 2: Proposal for alkannin biosynthesis according to NEELAKANTAN and SESHADRI [38].<smiles>CC(C)CCCC1CCc2c([O-])ccc([O-])c2C1</smiles>

$X X V I I$<smiles>CC1=CC(=O)C(CCC(C)CCCC(C)C)=CC1=O</smiles>

$X X V I I I$

from a phenol and two $\mathrm{C}_{5}$ units joined of 4-hydroxy-benzoate (XXIX) either head to tail (XXVII). The isolation of 5geranyl-2-methyl-1,4-benzoquinone (XXVIII) from Pyrola media [39] provides support for this view.

In tracer studies with alkannin, formed on the leaf surface of Plagiobothrys arizonicus, SCHMID and $\mathrm{Z}_{\text {ENK [ }}$ [40] postulated (Fig. 3) a pathway involving prenylation successively with two molecules of isopentenyl pyrophosphate or with geranyl pyrophosphate (XXX).

Recent data seem to contradict the results obtained by ZENK, as labeling studies indicated that the plants were unable to utilize exogenously administered mevalonic acid [41]. 
<smiles>O=C(O)c1ccc(O)cc1</smiles>

XXIX<smiles>CC(C)=CCCC(C)=CCOP</smiles>

$x x x$

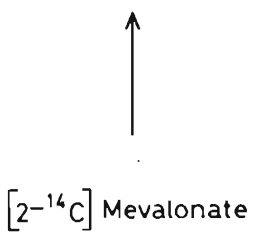

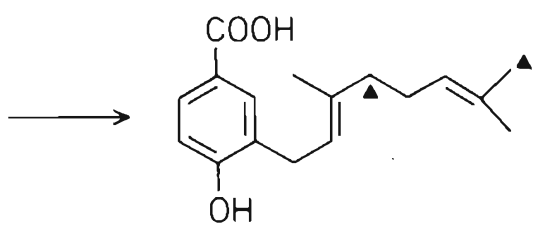

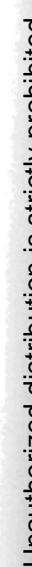

Alkannin

Fig. 3: Proposal biosynthetic sequence for alkannin by SCHMID and ZENK [40].

During the last few years $\mathrm{T}_{\mathrm{ABATA}}$ et al. $[42,43]$ studied the various physiological and physicochemical factors which influence the formation of naphthazarin pigments in Lithospermum erythrorbizon callus cultures.

\section{Biological Effects}

All isohexenylnaphthazarins are biologically extremely potent compounds, because they have pronounced antibacterial, antitumor and wound healing activities. The wound healing activity of all members has probably the most important clinical significance. It is of interest that extracts of Boraginaceous roots have been used for centuries as folk remedies for a variety of disorders such as eczema, keratodermia, dermatophytosis, corns callus, acne vulgaris, burns and even hemorrhoids [44, 45]. However, a scien- tific study to support this efficacy has only recently been started.

\section{Antibacterial activity}

A few years ago, a systematic study began on the antibacterial activity of these pigments [46]. In vitro, shikonin and its derivatives, except for anhydroalkannin, inhibited at a dose range of $10-160 \mu \mathrm{g} / \mathrm{ml}$ the growth of Staphylococcus aureous, Staphylococcus epidermidis, Sarcina lutea, Bacillus subtilis, but not that of Escherichia coli and Pseudomonas aeroginosa; some shikonin derivatives slightly inhibited the growth of Saccharomyces cerevisiae [16, 47, 48, 49].

Pigments (shikonin derivatives) from Lithospermum erythrorbizon callus cultures showed similar properties as those from plant roots $[42,43]$. Thus, the chloroform extracts of the callus cultures which contain large amounts of the pigments showed antibacterial action similar 
to that of the chloroform extract of the roots against Gram-positive bacteria [50]. Cell cultures are therefore a possible source of the naphthaquinones due to the decreasing availability and unsuccessful cultivation of this plant.

Shuxla it al. [8], studied the antibiotic activity of arnebins (alkannin derivatives from the roots of Arnebia nobilis) and found that $\beta, \beta$-dimethylacryl-hydroxyalkannin (Table I, Nr. XIV) exhibited the greatest antibacterial potency, inhibiting the growth of Gram-positive bacteria (Staphylococcus aureus and Bacillus subtilis) and fungi (Candida albicans and Cryptococcus neoformans) at a concentration $6.25 \mu \mathrm{g} / \mathrm{ml}$.

Studies [51] on the relationship of structure to antimicrobial properties of naphthaquinone pigments and other constituents of Alkanna tinctoria indicated that:

1. Polymerization of naphthaquinones results in a complete loss of their antimicrobial activity. This is particularly important because naphthaquinones are subject to polymerization in the presence of air, light and heat [52]. Thus, it is possible that during the isolation of these substances considerable pharmacological activity is lost due to polymerization.

2. The naphthaquinone moiety of alkannin and its esters appears to be necessary for antimicrobial activity. Alkylation of the phenolic groups leads to complete loss of activity, while acylation does not appear to influence the antibacterial properties.

3. Since alkannin and its esters are active, it appears that the aliphatic side chain acts as a delivery system for the naphthaquinone. Thus, it is suggested that esterification at the aliphatic hydroxyl group might lead to products with enhanced antimicrobial activity.

\section{Antitumor activity}

The National Cancer Institute (NCI, Maryland, USA) has reported the cancer screening data for 1599 quinones [53]. Approximately $15 \%$ of them show activity in one or more of the screens employed, that is, with L1210 leukemia, W-256 system cells, CA-755, S-180, and $\mathrm{KB}$ cells. Among the tested naphthaquinones are alkannin, $\beta, \beta$-dimethylacrylate and alkannin acetate [54]. From a structural point of view alkannin and their esters are suitable to function as bioreductive alkylating agents and show cytotoxic properties [55]. In fact, alkannin and naphthazarin (the parent ring system of alkannin) exhibited marked cytotoxic properties at $1 \times 10^{-7} \mathrm{M}$ when tested on cultured hamster cells [56]. According to this function as bioreductive alkylating agents, alkannin and its derivatives (which are functionalized with a leaving group $\mathrm{X}$ at the $\alpha$-position on the side chain, Fig. 4 , XXXI) should be reduced in vivo to the hydroquinone XXXII. Subsequent loss of $\mathrm{HX}$ would give the hydroquinone XXXIII, which would then function as a potent alkylating agent via a Michael addition reaction (Fig. 4).

The above mentioned results point to a serious problem since alkannin is used for the artificial coloring of certain foods [7]. The cytotoxic properties already investigated in vitro [56] should be studied in vivo as well. However, alkannin was fed to mice for fifteen weeks at $1 \%$ of the diet with no evidence of toxicity [57].

It should be also noted that 2,3-bis (substituted methyl)naphthazarins and related compounds were synthesized [58]. 
<smiles>[X]C1CC=C(C)C2=C1C(=O)c1c(O)ccc(O)c1C2=O</smiles>

$\mathrm{XXXI}$<smiles></smiles>

$x \times x I I$

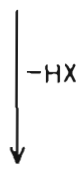

(ch

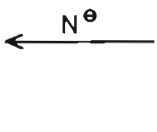<smiles>CC1=CCC=C2C(=O)c3c(O)ccc(O)c3C(O)=C12</smiles>

$x \times x 111$

Fig. 4: Bioreductive alkylating function of isohexenylnaphthazarins.

$\mathrm{X}=$ leaving group (-OH or $-\mathrm{OCOR})$.

$\mathrm{N}=$ nucleophilic center on a biomolecule (DNA, reductase, or the like).

These compounds were prepared as potential biological alkylating agents. Screening results indicated that 5,8 -bis (benzoyloxy)-2,3-dimethyl-1,4-naphthaquinone possessed borderline activity against leukemia P388 and that naphthazarin diacetate possessed confirmed cytotoxicity against the cell culture of human epidermoid carcinoma of the nasopharynx.

\section{Wound healing activity}

Though Anchusa tinctoria and Alkanna tinctoria have been mentioned in the "Greek Herbal of Dioscorides" [45] for the healing of wounds, it was only 1978 that this medicinal property has been confirmed and that the active components of the roots weredetermined [59]. Recently

the wound healing properties of alkannin esters were studied in the Dermatological Clinic of Heidberg Hospital (Hamburg, W. Germany) by the double blind method and were further assessed on another series of patients in Andreas Syngrou Hospital for Skin Diseases (Athen, Hellas).

The clinical studies in the Heidberg Hospital lasted for 3 years and involved 72 patients suffering from indolent ulcers (ulcus cruris), unsuccessfully treated over long periods with other known therapeutic agents [60]. Topical application of this speciality for 5 to 6 weeks resulted in complete healing or at least marked improvement. Furthermore, no skin inflammation was observed during therapy. The percentage of success was $80 \%$. 

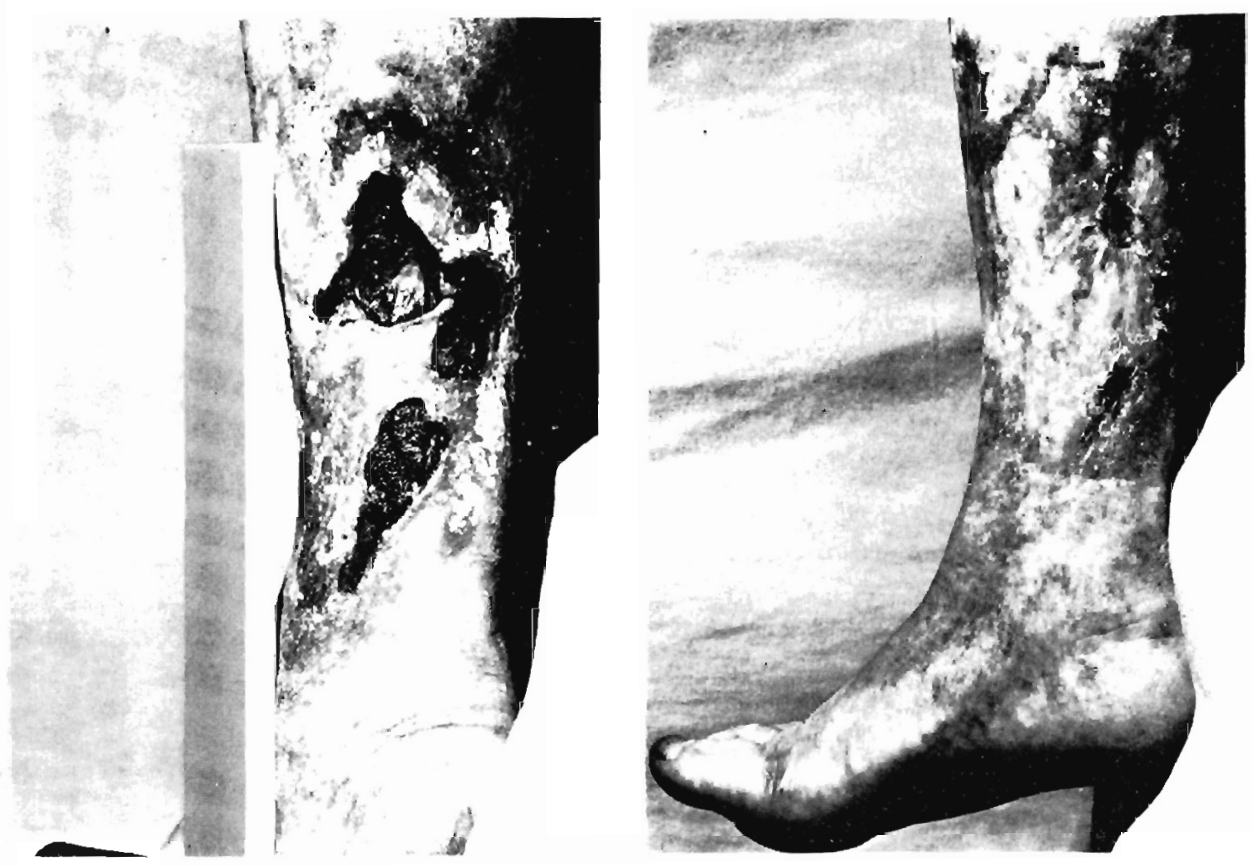

Fig. 5: A 62 old woman. Indolent ulcer of the right leg, ten years' duration.

Before treatment.

After 4 weeks' treatment with alkannin esters.

The dramatic improvement in a particularly severe case of ulcus cruris is shown in Figure 5.

\section{Other biological and pharmacological activities}

During the past thirty years various biological and pharmacological activities of the discussed naphthaquinones have been reported. It has been found that: (1) shikonin inhibits yeast carboxylase [61]; (2) a 10\% aquatic tincture and 1:1 extract of the Lithospermum purpurocaeruleum was bactericidal for pyogenic bacteria and Escherichia coli. The preparations accelerated epithelization and healing of wounds and burns [62]; (3) alkannin oily solutions possess protective properties against solar and uv-radiation [63]; (4) shikonin in concentrations of $20-30 \mu \mathrm{g} /$

$\mathrm{ml}$ had a bactericidal effect on lactic acid and acetic acid bacteria $[64,65]$; (5) shikonin stimulated peroxidase from horseradish [66]; (6) shikonin had a significant antiamoebic action on Entamoeba histolytica when added at $0.5-10 \mu \mathrm{g} / \mathrm{ml}$ to the medium. However, when administered orally, shikonin showed weak therapeutic effects [67]; (7) shikon (Lithospermum officinale L. var. erythrorbizon) has antiinflammatory action and a slight antipyretic effect [68]. Furthermore, shiunko (a main prescription of shikon) is an effective ointment for cutaneous injuries $[69,70]$.

\section{Conclusion}

Alkannin pigments possess potent antiinflammatory, antibacterial and even anti- 
cancer action. However, their strong wound healing properties in combination with lack of side effects, consecrate them as a new class of drugs, which is coming to fill a serious gap in the therapeutic armamentarium. Present research is dealing with the effect of these pigments on collagen synthesis.

\section{References}

1. Pulizzer, G:: Osterr. Bot. Zeitschrifr; 65, 177 (1915).

2. Thomson, R. H.: Naturally Occurring Quinones, New York 1971, Academic Press.

3. Bentley, K. W.: The Natural Pigments, New York 1960, Interscience Publishers.

4. Ballantine, J.: Phytochemistry, 8, 1586 (1969).

5. Mathis, C.: in T. Swain (Ed.), Comparative Phytochemistry, pp. 262-267, London 1966, Academic Press.

6. Bole, P. V.: J. Sci. Industr. Res., C20, 188 (1961).

7. Jain, A. C. and S. K. Mathur: Bull. Soc. Inst. Sci., India, 28, 52 (1965); Chem. Abs., 66, $26143 \mathrm{~m}(1967)$.

8. Shukla, Y. N., J. S. Tandon, D. C. Bhakuni and M. M. Dhar: Experientia, 25, 357 (1969).

9. ShukJa, Y. N., J. S. Tandon, D. S. Bhakuni and M. M. Dhar: Phytochemistry, 10, 1909 (1971).

10. Benk, E.: Riechstoffe, Aromen, Körperpflegemittel, L, 3 (1967).

11. Steiner, F.: Mitteilung 6, der DFG-FarbstoffKommission, 2 Aufl., Weisbanden (1957).

12. Burriel, F. and J. Ramirez-Munoz: Anal. Soc. Españ. Fís. Quîm., 44B, 1149 (1948).

13. (a) Dubsky, J. and E. Wagner: Microchemie, 20,57(1936).

13. (b) Underwood, A. L. and W. F. Newmann: Anal. Chem., 21, 1348 (1949).

14. Brockmann, H.: Annalen, 521, 1 (1935).

15. Afzal, M. and M. Tofeeq:J. Chem. Soc., Perkin Trans, I, 14, 1334 (1975).

16. Papageorgiou, V. P., A. S. Mellidis and A. N. Sagredos: Chem. Chron., in press (1979).

17. Kyogoku, K., H. Terayama, Y. Tachi, 'T. Suzuki and M. Komatsu: Shoyakugaku Zasshi, 27. 24 (1973): Chem. Abs., 80, 112549u (1974).
18. Shukla, Y. N., J. S. Tandon and M. M. Dhar: Indian J. Chem., Il, 528 (1973); Chem. Abs:, 79, 115345q (1973).

19. Dušinský, G. and A. Szokolay: Nahrung, 4, 356 (1960); Chem. Abs., 54, 25346h (1960).

20. Krolikowska, M. and L. Swiatek: Diss. Pharm. Pharmacol., 18, 157 (1966); Chem. Abs., 65, $5870 b$ (1966).

21. Romanova, A. S. and A. I. Ban'kovskii: Khim Prirodn. Soedin., Akad. Nauk. Uz.SSR, 3, 226 (1965); Chem. Abs., 63, 16773h (1965).

22. Tareeva, N. V., A. S. Romanova, A. I. Ban'kovskii and P. N. Kibal'chich: Khim. Prir Soedin., 2, 359 (1966); Chem. Abs., 66, 79524t (1967).

23. Morimoto, I., T. Kishi, S. Ikegami and Y Hirata: Tetrahedron Letters, 52, 4737 (1965).

24. Papageorgiou, V. P. and G. A. Digenis: in preparation (1979).

25. Papageorgiou, V. P.: Chem. Chron., 7, 45 (1978).

26. Morimoto, I. and Y. Hirata: Tetrahedron Letters, 3/, 3677 (1966).

27. Papageorgiou, V. P.: Planta Med., 31, 390 (1977).

28. Pelletier, J.: An. Chim. (Phys.), S1, 191 (1832); Annalen, 6, 27 (1833).

29. Bolley, P. and R. Wydler: Annalen, 62, 141 (1847).

30. Boldyrev, N. N.: Pharmatsiya, 10, 24 (1939); Khim, ref. Zh., S, 108 (1949).

31. Bisht, B. S., B. C. Kundu and B. Mukerji: J. Sci. Industr. Res., 20, 218 (1961).

32. Majima, R. and C. Kuroda: J. Chem. Soc. Japan, 39, 1051 (1918); Acta Phytochim. (Tokyo), 1, 43 (1922).

33. Arakawa, H. and M. Nakazaki: Chem. and Ind. (London), 947 (1961).

34. Afzal, M. and M. Tofeeq: J. Chem. Soc., Perkin I, 1579 (1976).

35. Sankawa, U., Y. Ebizuka, T. Miyazaki, Y. Isomura and F. Fukuoka: Chem. Pharm. Bull., 25,2392 (1977).

36. Papageorgiou, V. P.: Planta Med., 37, 185 (1979).

37. Kobayashi, M., Y. Terui, K. Tori and N. Tsuji: Tetrahedron Letters, 8, 619 (1976).

38. Neelakantan, S. and T. R. Seshadri: J. Sci. Industr. Res., A20, 448 (1961).

39. Burnet, A. R. and R. H. Thomson: J. Chem. Soc. (C), 857 (1968). 
40. Schmid, H. V. and M. H. Zenk: Tetrahedron Letters, 44, 4151 (1971).

41. Sankawa, U., Y. Ebizuka, S. Shibata and K. Yamasaki: Syoyakugaku Zasshi, 30, 183 (1976).

42. Tabata, M., H. Mizukami, N. Hiraoka, M. Konoshima: Phytochemistry, 13, 927 (1974).

43. Tabata, M., H. Mizukami, N. Hiraoka, M. Konoshima: Abst. 12th Phytochem. Symp. Japan, Kyoto, p.p. 1-8 (1976).

44. Hsu, H. Y. and W. G. Peacher: Chinese herb Medicine and Therapy, Nashville, Tenessee (1976), Aurora Publishers Inc.

45. Gunther, R.: The Greek herbal of Dioscorides, p. 421, New York 1959, Hafner.

46. Inagaki, I., M. Yamazaki, A. Takahashi, K. Ooye, S. Shibata and A. Takada: Daigaku Yakugakubu Kenkyu Nempo, 15, 27 (1967); Chem. Abs., 69, 41955h (1968).

47. Kyogoku, K., H. Terayama, Y. Tachi, T. Suzuki and M. Komatsu: Shoyakugaku Zasshi, 27, 31 (1973); Chem. Abs., 80, 52315c (1974).

48. Tanaka, Y. and T. Odani: Yakugaku Zasshi, 92, 525 (1972); Chem. Abs., 77, 96780t (1972).

49. Tanaka, Y., T. Odani and T. Kanaya: Shoyakugaku Zasshi, 28, 173 (1974); Chem. Abs., 83, $152418 \mathrm{u}$ (1975).

50. Tabata, M., H. Mizukami, S. Naoe and M. Konushima: Yakugaku Zasshi, 95, 1376 (1975); Biol. Abs., 62 (4), 18482 (1976).

51. Papageorgiou, V. P., A. Winkler, A. N. Sagredos and G. A. Digenis: Planta Med., 35, 56 (1979).

52. Vander Vijuer, L. M. and K. W. Gerritsma: J. Chromatogr., 114, 443 (1975).

53. Driscoll, J. S., G. F. Hazard, H. B. Wood and A. Goldin: Cancer Chemother., 4, I (1974).

54. Gupta, S. K. and I. S. Mathur: Indian J. Chancer, 9, 50 (1972).

55. Moore, H. W.: Science, 197, 527 (1977).

56. Papageorgiou, V. P., A. N. Sagredos, P. S.
Sabharwal, C. Gairola and G. A. Digenis: Abst. 23rd Academy of Pharmaceutical Science National Meeting, Phoenix, Arizona (USA), pp. 178 (1977).

57. Majlathova, L.: Nahrung, 15, 508 (1971); Chem. Abs., 76, 122513i (1972).

58. Paull, D. K., R. K. Y. Zee-Cheng and C. C. Cheng: J. Med. Chem. 19, 337 (1976).

59. Papageorgiou, V. P.: Experientia, 34, 1499 (1978).

60. Winkler, A.: Personal communication (1976).

61. Kuhn, R. and H. Beinert: Chem. Ber., 80, 101 (1947).

62. Yusubov, R. A.: Sb. Nauchn. Tr. Azerb. Nauchn.-Issled. Inst. Gematol. i Pereliv. Krovi, 6, 24I (1964); Chem. Abs., 62, 15326g (1965).

63. Crespa, A. A. and A. Crespa: Librada Span., 356, 371 (1970); Chem. Abs., 73, 44118f (1970).

64. Sherbanivs'kii, L. P.: Ukr. Bot. Zh., 28, 504 (1971); Chem. Abs., 76, 68687d (1972).

65. Shcherbanovs'kii, L. R., G. I. Nilov, Z. D. Rabinovich and V. A. Gorina: Rast. Resur., 8, 112 (1972); Chem. Abs., 76, 136281u (1972).

66. Blagonravova, L. N. and L. R. Shcherbanovs'kii: Prikl. Biokhim. Mikrobiol., 10, 666(1974); Chem. Abs., 82, 27824b (1975).

67. Rubinchik, M. A.: Mater. Vses. Konf. Issled. Lek. Rast. Perspekt. Ikn Ispol'z. Proizvod. Lek. Prep., 263 (1970); Chem. Abs., 83, 671h (1975).

68. Hayashi, M.: Nippon Yakurigaku Zasshi, 73, 177 (1977); Chem. Abs., 88, 44862d (1978).

69. Hayashi, M.: Nippon Yakurigaku Zasshi, 73, 193 (1977); Chem. Abs., 88, 44863e (1978).

70. Hayashi, M.: Nippon Yakurigaku Zasshi, 73, 205 (1977); Chem. Abs., 88, $44864 f$ (1978).

Address: Dr. V. P. Papageorgiou, Aristotle University, College of Engineering, Dept. of Chemical Engineering, Thessaloniki, Greece 